\title{
Effectiveness of Second-Line Agents in the Treatment of Uncomplicated Type 2 Diabetes Mellitus: An Observational Tertiary-Care Based Study
}

\author{
Rupam Gill', Shalini Adiga 2, ${ }^{2}$, Muralidhar Varma ${ }^{3}$ \\ 'Department of Pharmacology, Lady Hardinge Medical College, University of Delhi, New Delhi, INDIA. \\ 2Department of Pharmacology, Kasturba Medical College, Manipal Academy of Higher Education, Manipal, Karnataka, INDIA. \\ ${ }^{3}$ Department of Internal Medicine, Kasturba Hospital, Kasturba Medical College, Manipal Academy of Higher Education, Manipal, Karnataka, INDIA.
}

\section{ABSTRACT}

Background: The rational prescribing of second-line drugs in type 2 diabetes mellitus (DM) require clear guidelines. There is no sufficient empirical evidence to support the use of one second-line agent over the other and when to initiate second-line drug is still under discrepancy. Objectives: To analyze the utilization pattern and effectiveness of second-line agents in uncomplicated type 2 DM. Methodology: 240 uncomplicated type 2 DM patients who were $\geq 18$ years receiving either metformin/sulfonylurea or metformin+sulfonylurea was divided into four add-on treatment group 1, 2, 3 , 4; that were added pioglitazone, dipeptidyl peptidase-4(DPP-4) inhibitor, voglibose, and insulin [pre-mixed insulin (30\%regular/70\% NPH)] respectively and received the second-line agents for a duration of 6 months or longer. Effectiveness was based on the reduction in glycosylated hemoglobin $\left(\mathrm{HbA}_{1}\right)$, fasting plasma glucose (FPG) and postprandial blood glucose (PPBG) values over 3 and 6 months was done using repeated measures analysis of variance (ANOVA). Results: The mean difference for reduction in $\mathrm{HbA}_{1 \mathrm{C}}(\%)$ values at $3^{\text {rd }}$ and $6^{\text {th }}$ month with respect to baseline values was $1.32 \pm 0.72$ and $2.11 \pm 0.97 ; 1.19 \pm 0.27$ and $1.81 \pm 0.53 ; 1.16 \pm 0.41$ and $1.66 \pm 0.63 ; 0.97 \pm 0.16$ and $1.46 \pm 0.47$ for pioglitazone, DPP-4 inhibitor, voglibose, insulin respectively. The mean difference in FPG and PPBG levels at the $6^{\text {th }}$ month from baseline was $75 \pm 31.06$ and $115.3 \pm 40.32$; $77.91 \pm 37.95$ and $117 \pm 41.27 ; 85.87 \pm 21.75$ and $118.75 \pm 55.86 ; 91.38 \pm 31.8$
\end{abstract}

and $132.03 \pm 56.24$ for pioglitazone, DPP-4 inhibitors, voglibose and insulin respectively. Reduction in $\mathrm{HbA}_{1}, \mathrm{FPG}$, and PPBG was statistically significant within each group at each time interval with $p$-value $<0.001$. Conclusion: All the add-on groups exhibited a significant reduction in $\mathrm{HbA}_{1 c^{\prime}}, F \mathrm{~F}$, and PPBG over 3 and 6 months. DPP-4 inhibitors exhibited least hypoglycemic episodes. DPP-4 inhibitors are trending and marginally more effective second-line OHA in uncomplicated type 2 DM.

Key words: Anti-diabetic drugs, FPG, HbA ${ }_{1 C^{\prime}}$ PPBG, Second-line agents.

Key message: The present study gives information on the effectiveness of second-line agents when used in combination with metformin or sulfonylurea or both in type-2 DM during clinical practice. This study gives a real-world evidence on the glycemic index achieved with second-line add-on drugs having good efficacy and tolerability over a period of 6-months.

Correspondence

Dr. Shalini Adiga, Department of Pharmacology, Kasturba Medical College, Manipal Academy of Higher Education, Manipal-576104, Karnataka, India.

Phone:+91-9448521328

Email: shalini.adiga@manipal.edu

DOI: 10.5530/jyp.2018.10.74

\section{INTRODUCTION}

Diabetes is one of the leading cause of mortality and morbidity throughout the globe. ${ }^{1}$ In the recent years, the prevalence of type 2 diabetes has been on the rise in India with an average prevalence of $9.1 \%$ observed in 2013. ${ }^{2}$ Moreover, diabetes exerts a significant financial burden on the individuals, healthcare system, and the society due to chronicity of the nature of the disease. ${ }^{3}$ The cornerstone of management of diabetes is primarily the glucose-lowering therapies. ${ }^{4}$ Therefore, the healthcare professional organizations have laid guidelines for the stringent metabolic targets as the principle for diabetes management. ${ }^{5-6}$ Presently, there are eleven different classes of hypoglycemic agents along with numerous insulin preparations available as a treatment option for type 2 diabetes. $^{7}$ The confirmatory diagnosis of type 2 diabetes consists of $\mathrm{HbA}_{1 \mathrm{C}} \geq 6.5 \%$ along with fasting plasma glucose (FPG) $\geq 126 \mathrm{mg} / \mathrm{dL}$ and postprandial blood glucose $(\mathrm{PPBG}) \geq 200 \mathrm{mg} / \mathrm{dL}$. If $\mathrm{HbA}_{1 \mathrm{C}}$ is $\geq 7.5 \%$ at the time of diagnosis, it is advised to initiate pharmacological treatment with the oral hypoglycemic agent, i.e. metformin..$^{8-9}$ Whereas, insulin is started at first for the symptomatic patients presenting with markedly elevated $\mathrm{HbA}_{1 \mathrm{C}}$ and later can be switched to metformin. ${ }^{10}$ When to initiate second-line agents is still under discrepancy and there is no clear guideline in this regard. Nevertheless, it is stated that if the target $\mathrm{HbA}_{1 \mathrm{C}}$ is not achieved over a span of 3 months of treatment initiation; it is advised to add a second oral hypoglycemic agent or a glucagon-like peptide 1 (GLP-1) receptor agonists or a basal insulin. ${ }^{11}$

Metformin remains as the first line agent for type 2 diabetes management. ${ }^{12}$ There is no consensus to support the use of one second-line agent over the other. ${ }^{13}$ Due to the emergence of safety concerns with regards to stroke, heart failure, myocardial infarction, bladder cancer, and bone fractures; a decline was seen in the utilization pattern of rosiglitazone and pioglitazone after 2006 and 2011 respectively. ${ }^{14-15}$

Dual or triple combination therapy having complementary mechanisms of action is not only essential but also logical and necessary to achieve glycemic targets. ${ }^{16}$ Henceforth, in view of the limited Indian data, the present study was designed and aimed to investigate: (a) the utilization pattern of second-line agents; (b) analyze the indications for their initiation, and (c) the outcome analysis of combination therapies.

\section{MATERIALS AND METHODS}

This study was designed as a descriptive retrospective study, conducted in Department of Pharmacology and Internal Medicine, Kasturba Medical College, Manipal from January 2015 to July 2016. The Institutional

This is an open access article distributed under the terms of the Creative Commons Attribution-NonCommercial-ShareAlike 4.0 License, which allows others to remix, tweak, and build upon the work non-commercially, as long as the author is credited and the new creations are licensed under the identical terms. 
Ethics Committee (IEC) approval was obtained before initiating the study (letter no. IEC: 538/2014). Four add-on treatment group 1, 2, 3, 4 were added pioglitazone, dipeptidyl peptidase-4(DPP-4) inhibitor, a-Glucosidase inhibitor (voglibose), and insulin [pre-mixed insulin (30\%regular/70\%NPH)] respectively and received the second-line agents for a duration of 6 months or longer.

Study sample: Uncomplicated type $2 \mathrm{DM}$ for the first-time initiated on second-line add-on agent during 01 July 2012 to 01 July 2015.

Sample size: Calculated statistically using SPSS software version 16.0. Considering a reduction of $0.2 \%$ in $\mathrm{HbA}_{1 \mathrm{C}}$ and $80 \%$ power of the study; a sample size of 60 in each group was derived. Henceforth, a sample size of 240 was taken for studying four different drug groups.

Source of data: Medical records department, Kasturba Hospital, Manipal. Study duration: 18 months.

\section{Inclusion criteria}

- $\quad$ Age $\geq 18$ years and either sex.

- Uncomplicated type $2 \mathrm{DM}$ as per WHO criteria.

- Previously receiving at least one oral antidiabetic drug (metformin or sulfonylurea) or dual-combination therapy (metformin+ sulfonylurea) and for the first-time initiated on a second-line add-on agent i.e., pioglitazone or DPP-4 inhibitor (sitagliptin/ vildagliptin) or $\alpha$-glucosidase inhibitor (voglibose) or insulin.

\section{Exclusion criteria}

- Type 1 DM

- Gestational DM

- Diabetic ketoacidosis

- Hyperosmolar hyperglycemic nonketotic coma

- Diabetic microvascular and macrovascular complications

- Clinically significant renal and liver disease

Following details were collected for subjects fulfilling inclusion criteria:

- Demographic data

- Duration of initial antidiabetic treatment before the initiation of second-line add-on agents and previously prescribed OHAs.

- $\mathrm{HbA}_{1 \mathrm{C}}(\%), \mathrm{FPG}(\mathrm{mg} / \mathrm{dL})$, PPBG $(\mathrm{mg} / \mathrm{dL})$ at baseline, 3 and 6 months respectively after the initiation of second-line agents.

\section{Statistical Analysis}

SPSS software version 16.0 was used for data analysis. The descriptive statistics i.e., mean \pm standard deviation, median, interquartile range, number, and percentage were used to describe the data. The repeated measures analysis of variance (ANOVA) was used to analyze the primary parameters at three-time intervals i.e., at baseline, $3^{\text {rd }}$ month, and $6^{\text {th }}$ month for respective groups. The p-value $<0.05$ was considered as statistically significant.

\section{RESULTS}

The study population consisted of 135 males (56.3\%) and 105 females (43.8\%). The mean age of the subjects was $56.79 \pm 11.73$ years, ranging from 21-87 years. The demographic details of the study population have been described in [Table 1]. Metformin was the most commonly prescribed first-line antihyperglycemic agent followed by glimepiride and glibenclamide. The average dose of previous anti-diabetic medications was: glibenclamide $6.18 \mathrm{mg}$ /day, glipizide $9.8 \mathrm{mg}$ /day, gliclazide $97.33 \mathrm{mg} /$ day, glimepiride $6.16 \mathrm{mg} /$ day, and metformin $1267 \mathrm{mg} /$ day.

The number of patients utilizing the second-line add-on agents was 54, 68,52 , and 66 in pioglitazone, DPP-4 inhibitor, voglibose, and insulin group respectively. The pattern of antidiabetic drug use amongst the
Table 1: Demographic details of study population.

\begin{tabular}{ccccc}
\hline Parameters & Group 1 & Group 2 & Group 3 & Group 4 \\
\hline $\begin{array}{c}\text { Number of } \\
\text { patients (n) }\end{array}$ & 54 & $68^{*}$ & 52 & 66 \\
Mean age (years) & $54 \pm 11$ & $57 \pm 12$ & $56 \pm 10$ & $59 \pm 13$ \\
Sex & & & & \\
Male n (\%) & $31(57.41)$ & $37(54.41)$ & $29(55.77)$ & $38(57.57)$ \\
Female n (\%) & $23(42.59)$ & $31(45.59)$ & $23(44.23)$ & $28(42.43)$ \\
Occupation (n) & & & & \\
Service & 14 & 22 & 18 & 10 \\
Business & 8 & 7 & 3 & 6 \\
Retired & 4 & 5 & 3 & 10 \\
Student & 0 & 1 & 0 & 1 \\
Laborer & 2 & 1 & 0 & 0 \\
Agriculturist & 7 & 7 & 5 & 12 \\
Unemployed & 19 & 25 & 23 & 27 \\
Smokers n (\%) & $16(29.62)$ & $18(26.47)$ & $8(15.38)$ & $10(15.15)$ \\
Alcoholics n (\%) & $16(29.62)$ & $20(29.41)$ & $7(13.46)$ & $14(21.21)$ \\
Drug Therapy n (\%) & & & & \\
Glibenclamide & $7(22.6)$ & $4(12.9)$ & $6(19.4)$ & $14(45.2)$ \\
Glipizide & $1(6.7)$ & $5(33.3)$ & $3(20)$ & $6(40)$ \\
Gliclazide & $3(42.9)$ & $1(14.3)$ & $0(0)$ & $3(42.9)$ \\
Glimepiride & $21(22.3)$ & $35(37.2)$ & $17(18.1)$ & $21(22.3)$ \\
Metformin & $52(24.1)$ & $63(29.2)$ & $51(23.6)$ & $50(23.1)$ \\
\hline The & & & &
\end{tabular}

$\mathrm{n}=$ number of patients

Group 1: Pioglitazone; Group 2: DPP-4 inhibitors (sitagliptin/vildagliptin); Group 3: $\alpha$-Glucosidase inhibitor (voglibose); Group 4: Insulin "sitagliptin = 37; vildagliptin $=31$

"Pre-mixed insulin (30\% regular $/ 70 \%$ NPH $)=60$; rapid acting insulin $=6$.

study population with duration of diabetes has been depicted in [Figure 1]. The pattern of various combination therapies has been summarized in [Figure 2]. The average dose of second-line add-on agents used daily was pioglitazone $17.88 \mathrm{mg}$, sitagliptin $52.70 \mathrm{mg}$, vildagliptin $50 \mathrm{mg}$, voglibose $0.29 \mathrm{mg}$ respectively. Insulin was used at a mean dose of 24.86, 15.11 and 16.23 units/day in the morning, afternoon and night respectively. The baseline characteristics of the study population have been described in [Table 2]. The mean $\mathrm{HbA}_{1 \mathrm{C}}$ observed was 9.99\% with standard deviation (SD) of $2.43 \%$. The mean FPG and PPBG of the subjects was $218 \pm 78.20$ $\mathrm{mg} / \mathrm{dL}$ and $305.64 \pm 106.14 \mathrm{mg} / \mathrm{dL}$ respectively.

The most common reason to initiate add-on therapy was uncontrolled type 2 diabetes measured as the high glycemic index in all respective groups. Though, the other leading causes were morbid obesity and dyslipidemia; infections and poor compliance with oral hypoglycemic agents lead to the initiation of insulin therapy as shown in [Figure 3].

The mean difference for reduction in $\mathrm{HbA}_{1 \mathrm{C}}$ (\%) values at 3 and 6 months with respect to baseline values was $1.32 \pm 0.72$ and $2.11 \pm 0.97$ for pioglitazone; $1.19 \pm 0.27$ and $1.81 \pm 0.53$ for DPP-4 inhibitor; $1.16 \pm 0.41$ and $1.66 \pm 0.63$ for voglibose; $0.97 \pm 0.16$ and $1.46 \pm 0.47$ for insulin respectively. The reduction in $\mathrm{HbA}_{1 \mathrm{C}}$ was found statistically significant within each group at each time interval with p-value $<0.001$ as depicted in [Figure 4]. The mean difference for glycosylated hemoglobin at 3 months was: group 1: $1.32 \pm 0.72$; group 2: $1.19 \pm 0.27$; group 3 : $1.16 \pm 0.41$; group 4: $0.97 \pm 0.16$. The mean difference for glycosylated hemoglobin at 6 months was: group 1: $2.11 \pm 0.97$; group 2: $1.81 \pm 0.53$; group 3: $1.66 \pm 0.63$; group 4: $1.46 \pm 0.47$. The mean reduction in FPG and PPBG for respective groups 




Figure 1: Median duration of type 2 diabetes mellitus for adding second-line anti-diabetic drugs.

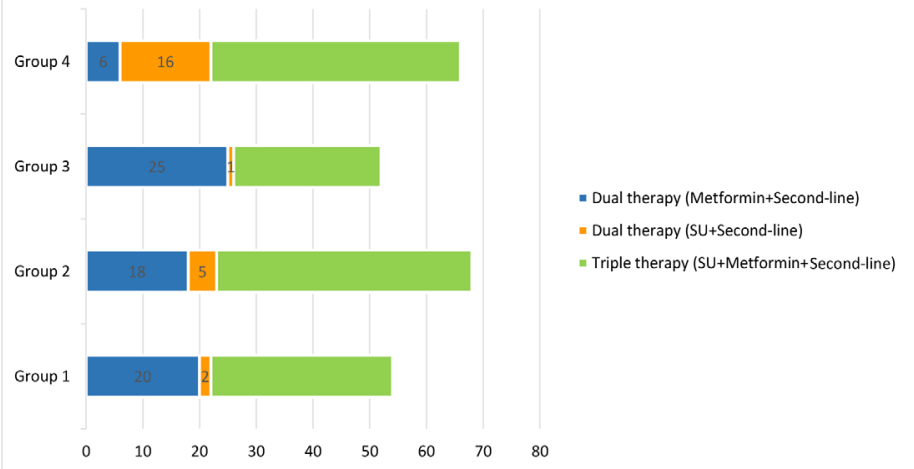

Figure 2: Pattern of antidiabetic drug prescriptions in different groups.

Table 2: Baseline Characteristics of the patients.

\begin{tabular}{ccccc}
\hline Parameters & $\begin{array}{c}\text { Group 1 } \\
\text { (Pioglitazone) }\end{array}$ & $\begin{array}{c}\text { Group 2 } \\
\text { (DPP-4 inhibitor) }\end{array}$ & $\begin{array}{c}\text { Group 3 } \\
\text { (Voglibose) }\end{array}$ & $\begin{array}{c}\text { Group 4 } \\
\text { (Insulin) }\end{array}$ \\
\hline Weight $(\mathrm{kg})$ & $67.17 \pm 14.23$ & $66.34 \pm 10.93$ & $65.25 \pm 13.45$ & $66.68 \pm 15.10$ \\
$\mathrm{HbA}_{1 \mathrm{C}}(\%)$ & $10.31 \pm 2.87$ & $9.65 \pm 1.94$ & $9.62 \pm 2.40$ & $10.39 \pm 2.48$ \\
FPG (mg/dL) & $210.19 \pm 86.02$ & $211.26 \pm 74.43$ & $217.75 \pm 64.72$ & $231.55 \pm 84.69$ \\
PPBG (mg/dL) & $298.93 \pm 101.05$ & $293.81 \pm 94.58$ & $304.96 \pm 105.97$ & $323.86 \pm 120.63$ \\
ESR (mm/hr) & $20(12,42)$ & $20(12,51)$ & $29(15,48)$ & $30(19,51)$ \\
SBP (mm Hg) & $121.96 \pm 10.66$ & $126.85 \pm 11.49$ & $121.35 \pm 17.45$ & $130.12 \pm 14.47$ \\
DBP (mm Hg) & $79.11 \pm 6.59$ & $81.32 \pm 6.44$ & $79.00 \pm 6.07$ & $82.97 \pm 8.09$ \\
Pulse (beats/min) & $88.61 \pm 6.00$ & $78.74 \pm 4.93$ & $74.85 \pm 6.88$ & \\
Hb (g/dL) & $12.43 \pm 1.84$ & $12.40 \pm 1.57$ & $12.64 \pm 1.90$ & $81.73 \pm 8.76$ \\
\hline
\end{tabular}

*values expressed as median (Q1, Q3).

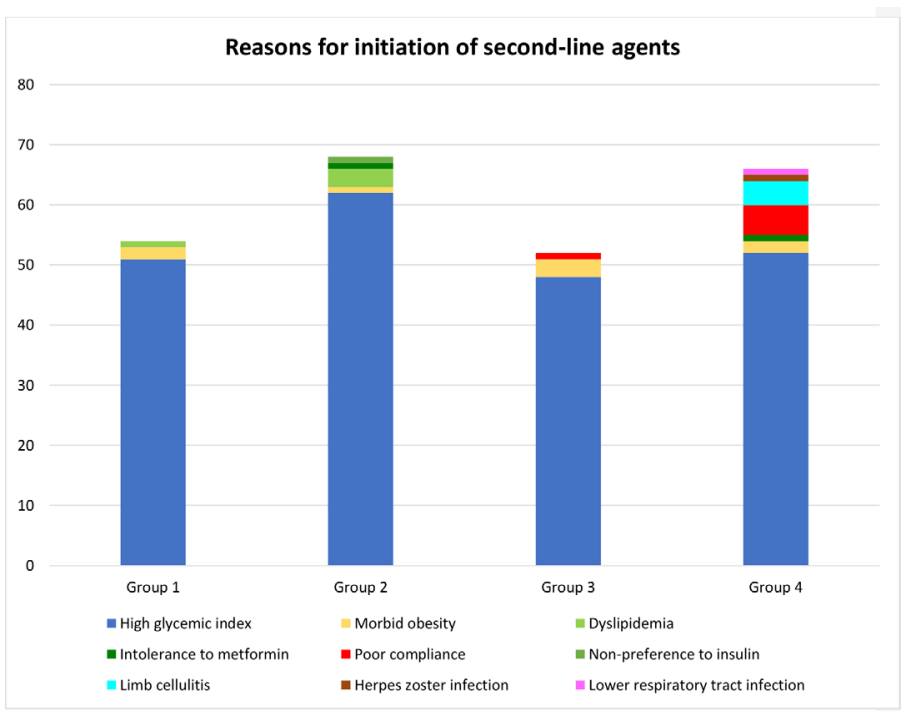

Figure 3: Enumeration of reasons for initiation of second-line agents in various antidiabetic treatment groups.

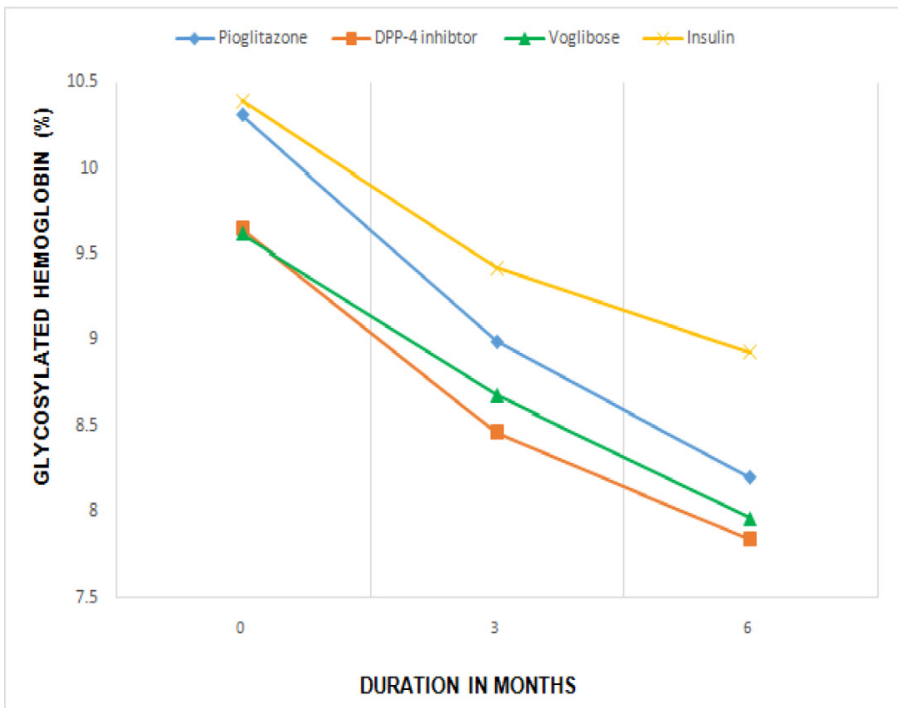

Figure 4: Reduction in $\mathrm{HbA}_{1}$ levels in the different group of second-line agents. 
Gill, et al.: Effectiveness of Second-Line Agents in Uncomplicated Type 2 Diabetes

Table 3: Change in FPG levels after the initiation of second-line agents.

\begin{tabular}{|c|c|c|c|c|c|}
\hline Add-on drug therapy & $\begin{array}{l}\text { FPG value at baseline } \\
\qquad(\mathrm{mg} / \mathrm{dL})\end{array}$ & $\begin{array}{l}\text { FPG value at } 3 \\
\text { months (mg/dL) }\end{array}$ & $\begin{array}{c}\text { FPG value at } 6 \text { months } \\
(\mathrm{mg} / \mathrm{dL})\end{array}$ & $\begin{array}{l}\text { Mean diff. at } 3 \text { months } \\
(\mathrm{mg} / \mathrm{dL})\end{array}$ & $\begin{array}{c}\text { Mean diff. at } 6 \text { months } \\
(\mathrm{mg} / \mathrm{dL})\end{array}$ \\
\hline $\begin{array}{c}\text { Group } 1 \\
\text { (Pioglitazone) }\end{array}$ & $210 \pm 86.02$ & $150 \pm 63.19$ & $135 \pm 54.96$ & $60 \pm 22.83^{*}$ & $75 \pm 31.06$ \\
\hline $\begin{array}{c}\text { Group } 2 \\
\text { (DPP-4 inhibitor) }\end{array}$ & $211 \pm 74.43$ & $148.85 \pm 48.61$ & $133.09 \pm 36.48$ & $62.15 \pm 25.82^{*}$ & $77.91 \pm 37.95^{*}$ \\
\hline $\begin{array}{c}\text { Group } 3 \\
\text { (Voglibose) }\end{array}$ & $217.75 \pm 64.72$ & $154.67 \pm 55.11$ & $131.88 \pm 42.97$ & $63.08 \pm 9.61^{*}$ & $85.87 \pm 21.75^{*}$ \\
\hline $\begin{array}{l}\text { Group } 4 \\
\text { (Insulin) }\end{array}$ & $231.55 \pm 84.69$ & $172.24 \pm 70.05$ & $140.17 \pm 52.89$ & $59.31 \pm 14.64^{*}$ & $91.38 \pm 31.8^{*}$ \\
\hline
\end{tabular}

"p-value $<0.001$.

Table 4: Change in PPBG values in the different groups of second line agents.

\begin{tabular}{|c|c|c|c|c|c|}
\hline Add-on drug therapy & $\begin{array}{l}\text { PPBG value at baseline } \\
\text { (mg/dL) }\end{array}$ & $\begin{array}{l}\text { PPBG value at } 3 \\
\text { months (mg/dL) }\end{array}$ & $\begin{array}{l}\text { PPBG value at } 6 \\
\text { months (mg/dL) }\end{array}$ & $\begin{array}{c}\text { Mean diff. at } 3 \text { months } \\
(\mathrm{mg} / \mathrm{dL})\end{array}$ & $\begin{array}{c}\text { Mean diff. at } 6 \text { months } \\
(\mathrm{mg} / \mathrm{dL})\end{array}$ \\
\hline $\begin{array}{c}\text { Group } 1 \\
\text { (Pioglitazone) }\end{array}$ & $298.93 \pm 101.05$ & $217.26 \pm 76.95$ & $183.63 \pm 60.73$ & $81.67 \pm 24.1^{*}$ & $115.3 \pm 40.32^{*}$ \\
\hline $\begin{array}{c}\text { Group } 2 \\
\text { (DPP-4 inhibitor) }\end{array}$ & $293.81 \pm 94.58$ & $212.53 \pm 68.73$ & $176.81 \pm 53.31$ & $81.28 \pm 25.85^{*}$ & $117 \pm 41.27^{*}$ \\
\hline $\begin{array}{c}\text { Group } 3 \\
\text { (Voglibose) }\end{array}$ & $304.96 \pm 105.97$ & $220.98 \pm 83.53$ & $186.21 \pm 50.11$ & $83.98 \pm 22.44^{*}$ & $118.75 \pm 55.86^{*}$ \\
\hline $\begin{array}{l}\text { Group } 4 \\
\text { (Insulin) }\end{array}$ & $323.86 \pm 120.63$ & $232.79 \pm 83.99$ & $191.83 \pm 64.39$ & $91.07 \pm 36.64^{*}$ & $132.03 \pm 56.24^{*}$ \\
\hline
\end{tabular}

"p-value $<0.001$.

has been summarized in [Table 3,4] and was statistically significant ( $p$-value $<0.001)$ within each group at 3 and 6 months respectively.

\section{DISCUSSION}

The present study aimed at investigating the utilization pattern of second-line agents as well as analyzing the outcome of treatment in terms of effectiveness of various second-line agents added for the first time to previously prescribed metformin or sulfonylureas or a combination of both. From 2003-2012 in the USA, the scenario of antidiabetic drug utilization had shown that $44.9 \%$ prescriptions had metformin monotherapy, pioglitazone prescription rates were nearly constant and rosiglitazone usage drastically declined. At the same time, newer approved drugs such as DPP-4 inhibitors were on a steady rise occupying $22 \%$ share. ${ }^{17}$ From 2008-2013 in Taiwan, DPP-4 inhibitors were the most prescribed agent for adjunctive therapy. ${ }^{18}$ In our findings from the year 2014, prescription of DPP-4 inhibitor had an increased share of $28.3 \%$. The upsurge in the trend towards DPP-4 inhibitor can be attributed to simple dosing regimen, oral administration, lesser adverse effects, better tolerability, insignificant hypoglycemic episodes, negligible weight alterations, and a desirable glycemic target achievement. ${ }^{19}$ The pioglitazone usage was reported more between 2012-2014 in the study undertaken and contributed to $22.5 \%$ prescriptions among second-line agents. The usage of pre-mixed insulin (30\% regular/70\% NPH) was reported as $27.5 \%$ compared to a study conducted in Shimoga district of Karnataka (28.57\%). ${ }^{20}$ The voglibose prescriptions were $21.7 \%$ that is commensurable to a Taiwan study focusing on $\alpha$-glucosidase inhibitors usage (19.21\%). ${ }^{21}$ Metformin was the most commonly prescribed first-line antihyperglycemic agent followed by glimepiride and glibenclamide. Among sulfonylureas the least prescribed one was gliclazide.

The median duration of diabetes was observed as 8 and 10 years respectively for adding pioglitazone and DPP-4 inhibitor. Hanefeld et al. showed the mean duration of diabetes to add pioglitazone as 7 years. ${ }^{22}$ The research studies have reported the mean duration of diabetes as 6.8 to 7.3 years for adding DPP-4 inhibitors. Our study identified the median duration of diabetes on a higher side in the group 2 probably due to increased availability and upsurge in popularity of DPP- 4 inhibitors in India after 2011. It was identified that the maximum number of patients i.e. 28 were prescribed voglibose as the most common second-line agent in those having received antihyperglycemic treatment for past 5 years. Insulin was the most prevalent second-line agent to be added to those receiving first-line drugs for past 10-20 years; while Riddle et al. study had 9.3 years for initiating NPH insulin. ${ }^{23}$ It depicts that the early stage of diabetes can be well managed by dual or triple oral hypoglycemic agent combination; while on the other hand, the elevated blood glucose levels seen in advanced diabetic stage require intensive insulin therapy.

In general, the glycemic control deteriorates in the first 3-5 years and $\mathrm{HbA}_{1 \mathrm{C}}$ levels increase at an average rate of $0.2-0.3 \%$ per year. Usually, the intensive monotherapy fails within 6 years of the initiation of antidiabetic agents. Even the patients who respond well to the monotherapy subsequently fail at a rate of $\geq 5 \%$ per year. Therefore, for the secondline agents to be effective, they should work either as insulin sensitizer e.g. pioglitazone or improve insulin resistance e.g. voglibose, sitagliptin, vildagliptin. Eventually, insulin therapy is commenced if drugs acting via either mechanism fail to produce effective results in terms of reducing or maintaining the $\mathrm{HbA}_{1 \mathrm{C}}$ levels. ${ }^{24}$

In the pioglitazone treatment group, the mean difference in $\mathrm{HbA}_{1 \mathrm{C}}$ at $3^{\text {rd }}$ and $6^{\text {th }}$ month with respect to baseline was $1.32 \pm 0.72$ and $2.11 \pm 0.97$ respectively which was significant with $\mathrm{p}$-value $<0.001$ at each time interval; a greater decline in $\mathrm{HbA}_{1 \mathrm{C}}$ at $6^{\text {th }}$ month. Usually, TZDs cause a decline in $\mathrm{HbA}_{1 \mathrm{C}}$ by $1-1.5 \%$ within 12 weeks which matched our finding; while $1.88 \%$ mean decline in $\mathrm{HbA}_{1 \mathrm{C}}$ at $3^{\text {rd }}$ month was observed by Al-Azzam et al. ${ }^{25} \mathrm{~A}$ systematic review covering pioglitazone combination studies 
over 12-26 weeks revealed a decrease in $\mathrm{HbA}_{1 \mathrm{C}}$ up to $2.6 \%$ though the results among different studies varied from $0.34-1.57 \%{ }^{26}$ The FPG in pioglitazone add-on group exhibited a mean decrease of 60 and $75 \mathrm{mg} / \mathrm{dL}$ at $3^{\text {rd }}$ and $6^{\text {th }}$ month respectively from the baseline which was significant $(\mathrm{p}<0.001)$ at both the time intervals. Previously conducted 12-week and 16-week pioglitazone add-on studies demonstrated a decline of $38 \mathrm{mg} / \mathrm{dL}$ and $20.5 \mathrm{mg} / \mathrm{dL}$ respectively in FPG. ${ }^{27}$

The present study observed a mean decline of $1.19 \pm 0.27$ and $1.81 \pm 0.53$ in $\mathrm{HbA}_{1 \mathrm{C}}$ at $3^{\text {rd }}$ and $6^{\text {th }}$ month respectively in the DPP- 4 inhibitor group. Similar findings were observed by Raz et al. and Goldstein et al. - a decline of $1 \%$ and $1.40-1.90 \%$ in $\mathrm{HbA}_{1 \mathrm{C}}$ over 18 and 24 weeks respectively. ${ }^{28-29}$ Our study included patients with $\mathrm{HbA}_{1 \mathrm{C}}>10 \%$ contrary to other studies where $\mathrm{HbA}_{1 \mathrm{C}}$ ranging from $7.5-8.5 \%$ were undertaken; a greater decline might be due to this variation. The voglibose add-on treatment group in the present study identified a mean decline of $1.16 \pm 0.41$ and $1.66 \pm 0.63$ in $\mathrm{HbA}_{1 \mathrm{C}}$ at $3^{\text {rd }}$ and $6^{\text {th }}$ month respectively from the initial values. A study by Jindal et al. in North Indian population gives supporting evidence; an average decrease in $\mathrm{HbA}_{1 \mathrm{C}}$ of $1.17 \%$ and $1.96 \%$ at $3^{\text {rd }}$ and $6^{\text {th }}$ month. ${ }^{30} \mathrm{In}$ present voglibose treatment group a mean reduction of 83.98 and 118.75 $\mathrm{mg} / \mathrm{dL}$ in PPBG at 3 and 6 months respectively which was statistically significant.

\section{Limitations}

The retrospective nature of study design and a smaller sample size were the limitations of this study. Analysis of the trend of second-line agents' prescription over 3-years was not feasible owing to small sample size, restrained study timeframe, and limited resources. A larger sample size could have provided sufficient data to compare the efficacy between the groups at respective time intervals. The parameters were recorded with a window period of $\pm 15-20$ days at $3^{\text {rd }}$ and $6^{\text {th }}$ month. Sub-group analysis based on the number of glucose-lowering drugs utilized [dual therapy (metformin/sulfonylurea+ second-line agent versus triple therapy (metformin+ sulfonylurea+ second-line agent)] was not carried out.

\section{CONCLUSION}

Type $2 \mathrm{DM}$ is a modern pandemic and requires lifelong treatment. Failure to achieve the glycemic target and rapid progression to complications are the main concerns in the management of diabetes. There are various antidiabetic agents available to lower blood glucose levels. There was a gradual shift in trend towards prescribing DPP-4 inhibitors over the recent years. Our study focused on the effectiveness of second-line agents in combination with metformin or sulfonylurea or both. Pioglitazone add-on group had the greatest decline in $\mathrm{HbA}_{1 \mathrm{C}}$ at $3^{\text {rd }}$ and $6^{\text {th }}$ month followed by DPP-4 inhibitor group. All the four add-on groups exhibited a significant reduction in FPG and PPBG when used as dual or triple combination therapy over 3 and 6 months. DPP- 4 inhibitor add-on group was found to be safe in terms of least hypoglycemic episodes. Therefore, it can be inferred that DPP-4 inhibitors are modestly effective second-line anti-diabetic agent in uncomplicated type 2 diabetes.

\section{ACKNOWLEDGEMENT}

The authors would like to thank the staff of Medical Records Department, Kasturba Hospital, Kasturba Medical College, Manipal and Department of Biostatistics, Manipal Academy of Higher Education, Manipal for their cooperation.

\section{ABBREVIATIONS}

ANOVA: Analysis of Variance; DM: Diabetes Mellitus; DPP-4: Dipeptidyl Peptidase-4; FPG: Fasting Plasma Glucose; GLP-1: Glucagon-like Peptide-1; $\mathbf{H b A}_{1 \mathbf{C}}$ : Glycosylated Hemoglobin; IEC: Institutional Ethics Committee; OHA: Oral Hypoglycemic Agents; PPBG: Postprandial
Blood Glucose; SD: Standard Deviation; SU: Sulfonylurea; TZDs: Thiazolidinediones; WHO: World Health Organization.

\section{CONFLICT OF INTEREST}

The authors declare no conflict of interest.

\section{SUMMARY}

The study focused on the real-world evidence regarding the indications for initiating second-line agents in uncomplicated type 2 diabetes mellitus and their effectiveness over a period ranging from 3-6 months. The high glycemic index was the primary reason for initiating second-line agents with DPP-4 inhibitors being relatively more prescribed antidiabetic medication in the recent years compared to other second-line agents. The median duration of type 2 diabetes prior to second-line agent initiation ranged form 5-10 years. All the four add-on groups showed significant reduction in FPG and PPBG when used as dual or triple combination regimen over 3-6 month period. DPP-4 inhibitors and pioglitazone demonstrated maximum decline in glycosylated hemoglobin over 6 month treatment duration; though there was an increased trend in DPP-4 inhibitors prescription.

\section{REFERENCES}

1. Roglic G, Unwin N, Bennett PH, Mathers C, Tuomilehto J, Nag S, et al. The Burden of Mortality Attributable to Diabetes Realistic estimates for the year 2000. Diabetes Care 2005;28(9):2130-5

2. Diabetesatlas. Org Belgium: International Diabetes Federation: IDF Diabetes Atlas $7^{\text {th }}$ Edition. 2014. Update [updated 2017; cited $2017 \mathrm{Jul}$ 10]. Available from: http://www.idf.org/diabetesatlas

3. Centers for Disease Control and Prevention. National diabetes fact sheet: national estimates and general information on diabetes and prediabetes in the United States. 2011. Atlanta, GA: US Department of Health and Human Services, Centers for Disease Control and Prevention. 2011:201(1).

4. Diabetes Control and Complications Trial Research Group. The effect of intensive treatment of diabetes on the development and progression of long-term complications in insulin-dependent diabetes mellitus. N Engl J Med. 1993;329(14):977-86.

5. Garber AJ, Abrahamson MJ, Barzilay JI, Blonde L, Bloomgarden ZT, Bush MA et al. Consensus statement by the American Association of Clinical Endocrinologists and American College of Endocrinology on the comprehensive type 2 diabetes management algorithm-2016 executive summary. Endocr Pract. 2016;22(1):84-113

6. Inzucchi SE, Bergenstal RM, Buse JB, Diamant M, Ferrannini E, Nauck M, et al. Management of hyperglycemia in type 2 diabetes: A patient-centered approach position statement of the American Diabetes Association (ADA) and the European Association for the Study of Diabetes (EASD). Diabetes Care. 2012;35(6):1364-79.

7. Alexander GC, Sehgal NL, Moloney RM, Stafford RS. National trends in treatment of type 2 diabetes mellitus, 1994-2007. Arch Intern Med. 2008;168(19):2088-94.

8. Care. Diabetesjournals. Org Arlington: Diabetes Care. American Diabetes Association. 2015. [updated 2018 Jan; cited 2016 Sep 10]. Available from: http://care. diabetesjournals.org/content/diacare/39/Supplement_1/S13.full.pdf.

9. Khunti K, Gray LJ, Skinner T, Carey ME, Realf K, Dallosso H, et al. Effectiveness of a diabetes education and self-management programme (DESMOND) for people with newly diagnosed type 2 diabetes mellitus: Three year follow-up of a cluster randomised controlled trial in primary care. BMJ. 2012;344:e2333.

10. Care. Diabetesjournals Org. Arlington: Diabetes Care. American Diabetes Association. 2015. [updated 2018 Jan; cited 2016 Sep 10]. Available from: https://www.ncbi.nlm.nih.gov/pmc/articles/PMC3537269/.

11. Care. Diabetesjournals Org. Arlington: Diabetes Care. American Diabetes Association. 2015. [updated 2018 Jan; cited 2016 Sep 10]. Available from: http:// care.diabetesjournals.org/content/33/Supplement_1/S11.

12. Morgan CL, Poole CD, Evans M, Barnett AH, Jenkins-Jones S, Currie CJ. What next after metformin? A retrospective evaluation of the outcome of second-line, glucose-lowering therapies in people with type 2 diabetes. J Clin Endocrinol Metab. 2012;97(12):4605-12.

13. Garber A, Abrahamson M, Barzilay J, Blonde L, Bloomgarden Z, Bush M, et al. AACE comprehensive diabetes management algorithm 2013. Endocr Pract. 2013;19(2):327-36

14. Bennett WL, Wilson LM, Bolen S, Maruthur N, Singh S, Chatterjee R, et al. Oral diabetes medications for adults with type 2 diabetes: An update. 2011. [Cited in 2016]. Available from: http://www.ncbi.nlm.nih.gov/books/NBK55754/

15. Rizos CV, Elisaf M, Mikhailidis DP, Liberopoulos EN. How safe is the use of 
thiazolidinediones in clinical practice? Expert Opin Drug Saf. 2009;8(1):15-32.

16. Kimmel B, Inzucchi SE. Oral agents for type 2 diabetes: An update. Clin Diabetes. 2005;23(2):64-76.

17. Hampp C, Borders-Hemphill V, Moeny DG, Wysowski DK. Use of antidiabetic drugs in the US, 2003-2012. Diabetes Care. 2014;37(5):1367-74.

18. Ou HT, Chang KC, Liu YM, Wu JS. Recent trends in the use of antidiabetic medications from 2008 to 2013: A nation-wide population-based study from Taiwan. J Diabetes. 2016;9(3):256-66.doi:10.1111/1753-0407.12408 Available from: http://onlinelibrary.wiley.com/doi/10.1111/1753-0407.12408/full.

19. Gitt AK, Bramlage P, Binz C, Krekler M, Deeg E, Tschöpe D. Prognostic implications of DPP-4 inhibitor vs. sulfonylurea use on top of metformin in a real world setting-results of the 1 year follow-up of the prospective Dia Regis registry. Int J Clin Pract. 2013;67(10):1005-14.

20. Suthar SD, Dholaria NK, Chavda DA, Chacko J, Bhansali NB, Gosai TR, et al. Drug utilization study in diabetic patients attending medicine outpatient department of a tertiary care hospital. Int J Diab Dev Ctries. 2015;35(1):8-13.

21. Hsu JC, Ross-Degnan D, Wagner AK, Cheng CL, Yang YH, Zhang F, et al. Utilization of oral antidiabetic medications in Taiwan following strategies to promote access to medicines for chronic diseases in community pharmacies. J Pharm Policy Pract. 2015;8(1):15. doi:10.1186/s40545-015-0035-5.

22. Hanefeld M, Brunetti P, Schernthaner GH, Matthews DR, Charbonnel BH. One-year glycemic control with a sulfonylurea plus pioglitazone versus a sulfonylurea plus metformin in patients with type 2 diabetes. Diabetes Care. 2004;27(1):141-7.

23. Riddle M. Combining sulfonylureas and other oral agents. Am J Med. 2000;108(6):15-22

24. Nathan DM, Buse JB, Davidson MB, Ferrannini E, Holman RR, Sherwin R, et al. Medical management of hyperglycemia in type 2 diabetes: a consensus algorithm for the initiation and adjustment of therapy a consensus statement of the American Diabetes Association and the European Association for the Study of Diabetes. Diabetes Care. 2009;32(1):193-203.

25. Al-Azzam SI, AlOmari M, Khader YS, AlMahasneh FA, Muflih SM, Altawalbeh S. Effects of pioglitazone add-on to gliclazide and metformin on glycemic control in patients with type 2 diabetes. Endocr Res. 2012;37(1):7-11.

26. Chilcott J, Tappenden P, Jones ML, Wight JP. A systematic review of the clinical effectiveness of pioglitazone in the treatment of type 2 diabetes mellitus. Clin Ther. 2001;23(11):1792-823.

27. Einhorn $D$, Rendell M, Rosenzweig J, Egan JW, Mathisen AL, Schneider RL, et al. Pioglitazone hydrochloride in combination with metformin in the treatment of type 2 diabetes mellitus: A randomized, placebo-controlled study. Clin Ther. 2000;22(12):1395-409.

28. Raz I, Chen Y, Wu M, Hussain S, Kaufman KD, Amatruda JM, et al. Efficacy and safety of sitagliptin added to ongoing metformin therapy in patients with type 2 diabetes. Curr Med Res Opin. 2008;24(2):537-50.

29. Goldstein BJ, Feinglos MN, Lunceford JK, Johnson J, Williams-Herman DE. Effect of initial combination therapy with sitagliptin, a dipeptidyl peptidase-4 inhibitor, and metformin on glycemic control in patients with type 2 diabetes. Diabetes Care. 2007;30(8):1979-87.

30. Jindal A, Gupta M, Sharma G, Mohan G, Tikoo D. Comparative evaluation of voglibose versus pioglitazone on glycaemic control and lipid profile in patients of type 2 diabetes mellitus on glimepiride and metformin in punjabi population. Int J Basic Clin Pharmacol. 2012;1 (3):160-7.

Article History: Submission Date : 16-04-2018; Revised Date : 02-05-2018; Acceptance Date : 23-05-2018.

Cite this article: Gill R, Adiga S, Varma M. Effectiveness of Second-Line Agents in the Treatment of Uncomplicated Type 2 Diabetes Mellitus: An Observational Tertiary-Care Based Study. J Young Pharm. 2018;10(3):334-9. 